Tạp chí Khoa học và Công nghệ Biển T12 (2012). Số 4. Tr 15 - 28

\title{
ĐÁNH GIÁ KHẢ NĂNG TỔN THƯƠNG TÀI NGUYÊN VÀ MÔI TRƯờNG KHU VỬC ĐẢO BẠCH LONG VỸ
}

\author{
TRẦ ĐỨC THẠNH, NGUYẼ̃N VĂN QUÂN
}

Viện Tài nguyên và Môi trường Biển

\begin{abstract}
Tóm tắt: Đảo Bạch Long Vỹ nằm giữa vịnh Bắc bộ có tiềm năng lớn về phát triển kinh tế xã hội và bảo tồn tư nhiên. Tuy nhiên, tài nguyên và môi trường khu vực chịu tác động mạnh tù̀ nhũ̃ng yếu tố tự nhiên bất lợi, trong đó có biến đổi khí hậu và các hoạt động nhân tác. Sủ dụng phuoong pháp phân tích ma trận, khả năng tổn thuoong của 13 đối tuợng tài nguyên và môi truòng Bạch Long Vỹ được đánh giá tổng hơp theo tác động của 5 yếu tố biến cố tự nhiên và 10 yếu tố hoạt động nhân tác. Chúng được phân cấp thành bốn nhóm có mức tổn thương khác nhau. Nhóm có khả năng tổn thương ở mức rất cao bao gồm: 1- HST rạn san hô, 2- HST bãi cát biển, 3- xói lở bờ đảo. Nhóm có khả năng tổn thuoong ở múc cao bao gồm: 1- nước ngầm, 2- nguồn lợi thuỷ sản, 3- HST bãi triều rạn đá, 4- chất luợng nước biển ven đảo, 5- cảnh quan và habitat nổi và 6- tài nguyên đất đảo. Nhóm có khả năng tổn thương mức trung bình bao gồm: 1- đa dạng sinh học và 2- HST đáy cứng. Nhóm có khả năng tổn thương ở mức thấp: 1cảnh quan ngầm và 2- HST đáy mềm.
\end{abstract}

\section{MỞ ĐẦU}

Bạch Long Vỹ (BLV) là một đảo xa bờ của Việt Nam nằm giữa vịnh Bắc bộ, có toạ độ địa lý $20^{\circ} 07^{\prime} 35^{\prime \prime}$ và $20^{\circ} 08^{\prime} 36^{\prime}$ " vỹ độ Bắc; $107^{\circ} 42^{\prime} 20^{\prime \prime}$ và $107^{\circ} 44^{\prime} 15^{\prime}$ ” kinh độ Đông, cách Hòn Dấu - Hải Phòng $110 \mathrm{~km}$, cách đảo Hạ Mai 70km, cách mũi Ta Chiao - Hải Nam $130 \mathrm{~km}$. Đảo rộng $3,1 \mathrm{~km}^{2}$, trong đó có $1,8 \mathrm{~km}^{2}$ đất tự nhiên, còn lại là thềm đá ngập triều. Đảo có vị trí chiến lược và tầm quan trọng đặc biệt đối với an ninh quốc phòng và chủ quyền quốc gia trên biển. Tiềm năng phát triển kinh tế - xã hội của huyện đảo to lớn do có lợi thế giao lưu trong và ngoài nước, có nguồn tài nguyên thiên nhiên tại chỗ đáng kể và tài nguyên vùng biển bao quanh giàu có. Theo Quyết định số 742/QĐ-TTg ngày 26/5/2010 của Thủ tướng Chính phủ, BLV là một trong số 16 khu bảo tồn biển Việt Nam.

Do tác động bất thường của tự nhiên, nhất là do biến đổi khí hậu và sức ép phát triển kinh tế - xã hội, các hợp phần tài nguyên và môi trường khu vực BLV sẽ bị tồn thương ở mức độ khác nhau, cần được đánh giá phân loại để có cơ sở cho quản lý, bảo vệ theo định hướng phát triển bền vững.

\section{HIÊNN TRẠNG TÀI NGUYÊN VÀ MÔI TRƯỜNG}

BLV là một đảo đá Đệ tam [19], tuổi Oligocen và Miocen giữa - Pliocen [20] có dạng đồi thoải, độ cao tuyệt đối $61 \mathrm{~m}$, nổi nên từ nền đồng bằng cát đáy vịnh có độ sâu (ảnh 1 và ảnh 2). Sườn ngầm đảo dốc và phân bậc, thềm triều đá ven đảo phát triển rộng, nền đáy biển ven đảo chủ yếu lộ đá gốc Đệ tam hoặc phủ trầm tích vụn thô cuội, cát [13]. Điều kiện khí hậu khu đảo không quá khắc nghiệt, trừ yếu tố lượng mưa thấp và lượng bốc hơi cao gây khả năng khô hạn và đôi khi bão, sóng lớn bất thường. Những đặc trưng hải văn 
về thuỷ triều và dao động mực nước, dòng chảy, chế độ sóng cho thấy hoàn lưu nước vùng biển quanh đảo khá tốt, khả năng tự làm sạch môi trường cao. Hoàn lưu nước biển ven đảo chịu ảnh hưởng sâu sắc của chế độ gió và sóng tác động theo mùa Đông Bắc và Tây Nam. Nước biển khu vực trong và có độ mặn cao $[2,15]$.

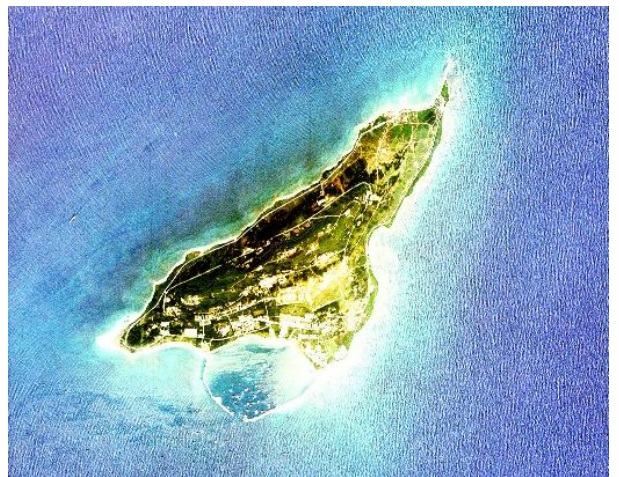

Ảnh 1. Đảo Bạch Long Vỹ nhìn từ ảnh vệ tinh

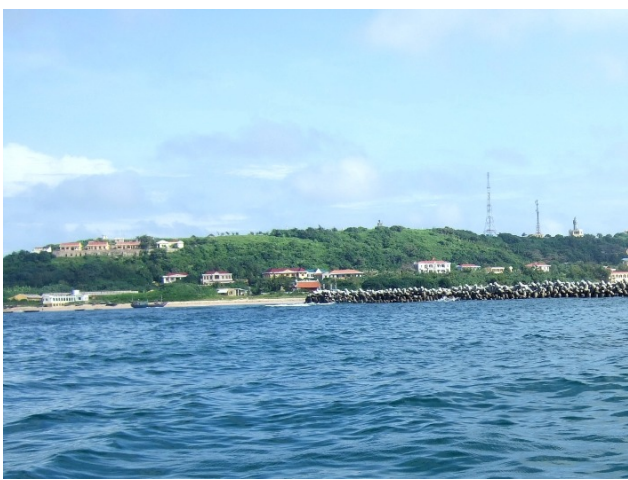

Ảnh 2. Đảo Bạch Long Vỹ (nguồn: Đàm Đức Tiến)

Hệ thực vật ở đảo có 126 loài thuộc 51 họ của 2 nghành thực vật bậc cao là Hạt kín và Khuyết thực vật. Cây chủ yếu là cây bụi, cỏ; cây gỗ rất ít, trừ một vài loại cây trồng, còn lại là dạng tái sinh [21]. Các hệ sinh thái (HST) có mặt ở vùng biển là HST bãi cát biển, HST bãi triều rạn đá, HST rạn san hô, HST đáy cứng và HST đáy mềm, tiêu biểu nhất là các HST bãi triều rạn đá (ảnh 3), rạn san hô (ảnh 4) và đáy cứng. Thành phần khu hệ sinh vật khá phong phú và đa dạng sinh học cao. Đã phát hiện được tổng số 1.015 loài, trong đó: thực vật ngập mặn 17 , rong biển 46 , cỏ biển 1 , thực vật phù du 210 , động vật phù du 125 , san hô 94 và cá biển 412 loài. Trong chúng, có nhiều loài kinh tế và một số loài được ghi vào sách đỏ $[15,17]$.

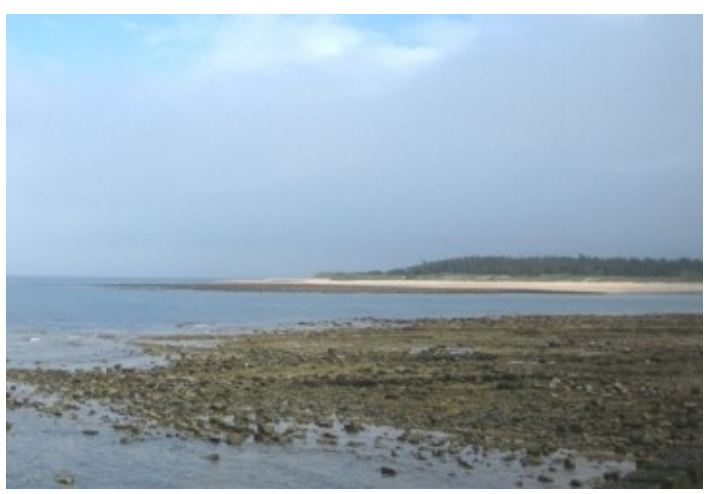

Ảnh 3. Bãi cát biển và bãi triều rạn đá (nguồn: Phan Trọng Trịnh)

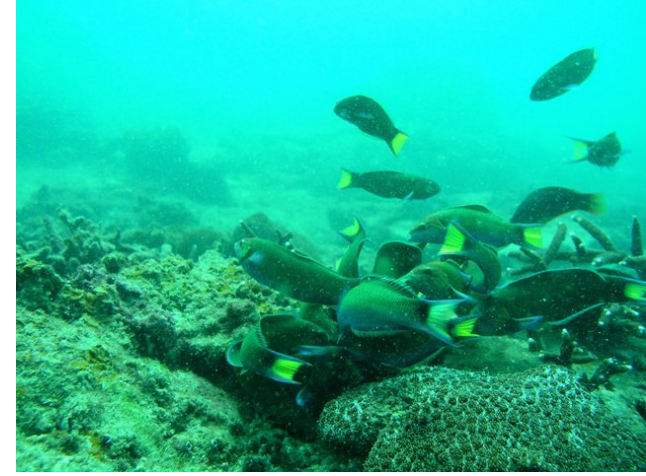

Ảnh 4. Rạn san hô đảo Bạch Long Vỹ (nguồn: Đàm Đức Tiến)

Tài nguyên thiên nhiên đảo và vùng biển BLV phong phú, đa dạng và có những nét đặc thù, nồi bật là tài nguyên vị thế có giá trị cao đối với chủ quyền vùng biển, an ninh quốc phòng và dịch vụ khai thác biển như nghề cá, hàng hải và dầu khí. Tài nguyên đất trên đảo [3], đất ngập nước [16], nước ngọt $[3,9,15]$ và vật liệu xây dựng $[7,12]$ mặc dù có số lượng không lớn nhưng rất quí giá và cần được sử dụng cân đối, hợp lý. Tiềm năng 
du lịch sinh thái, luồng bến có khả năng tạo thế mạnh kinh tế cho huyện đảo và triển vọng dầu khí khu vực rất đáng tin cậy với việc phát hiện Asphantit trong trầm tích trên đảo [20] và trầm tích tướng Sapropelit tuổi Oligoxen, rất tốt về chỉ tiêu $\mathrm{S}_{2}$ và $\mathrm{IH}$, thuộc Kerogen kiểu II, chỉ tiêu TOC cao, khoảng 1,5 - 7\%, cá biệt 49\%, thuận lợi cho sinh thành và bảo tồn hydrocacbon [21]. Tài nguyên sinh vật vùng biển $B L V$ rất lớn [10, 15], bao gồm nguồn lợi cá, động vật đáy, thực vật biển có giá trị thương phẩm cao, cung cấp nguồn thực phẩm, mỹ phẩm và dược phẩm. Trong đó, nổi bật là bào ngư, hải sâm, cá mú, mực ... tạo nên một ngư trường quan trọng ở giữa vịnh Bắc bộ [18]. Tiềm năng bảo tồn rất lớn gắn liền với đa dạng sinh học cao và đặc biệt là có HST rạn san hô rất phát triển ở phía Tây Bắc đảo $[11,17]$.

Hiện tại, cơ sở hạ tầng của đảo BLV chưa phát triển, kinh tế chủ yếu là dịch vụ, ngư nghiệp và nông nghiệp, nguồn sống hiện tại phần nhiều là lương bao cấp. Khai thác hải sản sát ven đảo chủ yêu do cư dân trên đảo. Khai thác hải sản tại ngư trường biển quanh đảo do ngư dân từ nhiều tỉnh, thậm chí cả từ nước ngoài, nên khó kiểm soát về tài nguyên và môi trường.

Do tác động tự nhiên và nhân sinh cảnh quan khu vực, đặc biệt cảnh quan nổi phần đảo, bờ và vùng triều đã bị thay đổi đáng kể. Quá trình biến dạng bờ đảo diễn biến phức tạp và đặc biệt xói lở bờ đảo có xu thế tăng đáng ngại [16].

Môi trường nền đáy vùng biển chủ yếu là đá gốc và cát cuội nên khả năng tích luỹ chất ô nhiễm thấp. Hàm lượng kim loại nặng $(\mathrm{Cu}, \mathrm{Pb}, \mathrm{Zn}, \mathrm{Cd}, \mathrm{Hg}, \mathrm{As})$ trong trầm tích qua nhiều đợt khảo sát thấp hơn nhiều giới hạn cho phép. Tuy nhiên, hàm lượng cyanua $(\mathrm{CN}-)$ có giai đoạn tập trung rất cao trong trầm tích đáy, trung bình $29,8 \mathrm{mg} / \mathrm{kg}$.

Môi trường nước biển BLV nói chung còn khá tốt, nước trong, độ đục thấp, độ mặn và độ $\mathrm{pH}$ diễn biến bình thường $[2,9,15,18]$. Các muối photphat $\left(\mathrm{PO}_{4}{ }^{3-}\right)$, amoni $\left(\mathrm{NH}_{4}{ }^{+}\right)$đều nằm dưới tiêu chuẩn cho phép mặc dù có lúc biểu hiện tăng cao trong cục bộ. Nước biển ven đảo có biểu hiện ô nhiễm và gia tăng tổng lượng nitrit $\left(\mathrm{NO}_{2}{ }^{-}\right)$và nitorat $\left(\mathrm{NO}_{3}{ }^{-}\right)$liên quan đến hoạt động dân sinh. Các chỉ số $\mathrm{DO}, \mathrm{B} \mathrm{D}_{5}$ và $\mathrm{COD}$ cho thấy nước biển $\mathrm{BLV}$ chưa bị ô nhiễm chất hữu cơ. Ô nhiễm dầu có chiều hướng gia tăng theo thời gian. Đặc biệt có những sự cố tràn dầu nghiêm trọng, không rõ nguồn gốc như năm 2007. Các kim loại nặng $(\mathrm{Cu}, \mathrm{Pb}, \mathrm{Zn}, \mathrm{Cd}, \mathrm{Hg}, \mathrm{As})$ đều thấp hơn tiêu chuẩn cho phép nhiều lần.

Môi trường sinh học có đa dạng sinh học cao nhạy cảm với tác động của con người. Cùng với ô nhiễm cyanua trong nước và trầm tích đáy có sự tập trung rất cao nồng độ cyanua trong cơ thể một số loài sinh vật như rong mơ, bào ngư và có thể là nguyên nhân góp phần gây chết hàng loạt san hô vào những năm 1997 - 1998 [4, 5, 6]. Gần đây, do quản lý tốt hơn, tình trạng ô nhiễm cyanua giảm hẳn. Trong thành phần khu hệ thực vật nổi, có mặt 32 loài tảo có khả năng gây hại thuộc 14 chi, ngành Pyrrophyta với mật độ còn thấp chưa vượt $7 \times 10^{5} \mathrm{~TB} / \mathrm{m}^{3}$. Trước mắt chưa thể hiện tác hại đối với môi trường nhưng trong tương lai, nếu điều kiện môi trường phì dinh dưỡng và có thuỷ triều đỏ, đây sẽ là một tiềm năng gây hại cho nghề cá và an toàn thực phẩm.

Như vậy, những vấn đề cấp bách đối với môi trường và tài nguyên biển BLV được xác định là: 1 - Khai thác quá mức và huỷ diệt làm thái hoá môi sinh và suy giảm nguồn lợi hải sản. Mật độ tầu đánh bắt cao, các phương tiện đánh bắt huỷ hoại môi sinh đặc biệt là 
cyanua đã có lúc thực sự trở thành thảm hoạ sinh thái làm chết hàng loạt san hô và suy giảm nghiêm trọng nguồn lợi hải sản đặc biệt là bào ngư; 2- Môi trường ô nhiễm ở một số yếu tố: dầu mỡ thường xuyên và cyanua cục bộ - tức thời trong nước, đất và cơ thể sinh vật, xuất hiện ô nhiễm nitrit và nitrat; 3 - Cảnh quan tự nhiên bị biến dạng, nơi cư trú của sinh vật bị huỷ hoại do tác động nhân sinh.

\section{KHẢ NĂNG TỔN THƯƠNG DO CÁC TÁC ĐỘNG TỰ NHIÊN}

\section{1. Áp lực và tác động}

Động đất và sóng thần. Chưa có tài liệu nào ghi nhận được chính thức có động đất và sóng thần ở khu vực đảo BLV. Tuy nhiên, xét về vị trí kiến tạo và những dấu hiệu khe nứt có trên đảo, khu vực đảo BLV là nơi có thể xảy ra khả năng địa chấn và xuất hiện sóng thần.

Bão và sóng lớn. Ảnh hưởng của bão đến khu vực khá lớn, gió trong bão đạt $50 \mathrm{~m} / \mathrm{s}$, sóng cao nhất ghi nhận được độ cao $7 \mathrm{~m}$ hướng Bắc - Tây Bắc vào tháng 9 , độ cao $6 \mathrm{~m}$ hướng Bắc - Đông Bắc vào tháng 10 và độ cao $6 \mathrm{~m}$ hướng Tây Nam vào tháng 7 . Khả năng bão và sóng lớn bất thường khá cao là một mối nguy hiểm cho các hoạt động dân sinh kinh tế và gây những hậu quả quá nặng nề về môi trường như bẻ gãy các rạn san hô, lật chìm tầu thuyền gây ô nhiê̂m tràn dầu, xói lở bờ lớn bất thường.

Khô hạn và mira lớn. Tổng lượng bức xạ cao $\left(132,5 \mathrm{Kcal} / \mathrm{cm}^{2} /\right.$ năm), cân bằng bức xạ cao $\left(84 \mathrm{Kcal} / \mathrm{cm}^{2} /\right.$ năm), số giờ nắng kéo dài (1700 giờ/năm), lượng mưa thấp $(1.031 \mathrm{~mm} /$ năm$)$, lượng bốc lớn $(1.461 \mathrm{~mm} / \mathrm{năm})$ là tiền đề gây khô hạn kéo dài ở BLV. Khô hạn gần như quanh năm, trừ số ít tháng mùa mưa khoảng tháng $6-9$. Khả năng khô hạn tăng rõ vào những năm gần đây do mưa ít và nắng nóng kéo dài vào những năm có ElNino, tiêu biểu vào năm 1997 - 1998. Khô hạn làm thiếu nước ngầm tầng mặt, cây cối khô héo, đất đai cằn cỗi, xâm nhập mặn từ nước từ nước biển, ... Tuy nhiên, có khi lại xảy ra mưa lớn, năm 1973 lượng mưa đạt $2.026 \mathrm{~mm}$, lượng mưa ngày đạt $278 \mathrm{~mm}$. Mưa lớn gây xói mòn đất mặt đảo, đục và ngọt nước ven đảo làm suy thoái các HST vùng triều và rạn san hô, cuốn trôi các chất ô nhiễm trên đảo xuống ven bờ đảo. Hiện nay, tình trạng cực đoan khô hạn và mưa lớn gia tăng thất thường.

Dâng cao mưc nước. Mực nước biển $\mathrm{BLV}$, trung bình $180 \mathrm{~cm}$, cao nhất $376 \mathrm{~cm}$ và thấp nhất $16 \mathrm{~cm}$. Ước tính, hiện nay mực nước biển khu vực dâng cao $2-3 \mathrm{~mm} / \mathrm{năm}$, do dâng cao mực nước biển toàn cầu liên quan khí hậu ấm lên và chuyển động kiến tạo [15].

Sự dâng cao mực nước do khí hậu trái đất ấm lên là một vấn đề lớn đã được nhiều tổ chức và nhà khoa học đánh giá. Cục bảo vệ môi trường Hoa Kỳ (EPA, 1983) đã đưa ra các kịch bản dâng cao mực nước thế giới rất khác nhau [1] (bảng 1).

Bảng 1. Mức độ dâng cao mực nước biển (cm) thế giới (EPA, 1983)

\begin{tabular}{|l|c|c|c|c|c|c|}
\hline Mức độ & $\mathbf{2 0 0 0}$ & $\mathbf{2 0 2 5}$ & $\mathbf{2 0 5 0}$ & $\mathbf{2 0 7 5}$ & $\mathbf{2 1 0 0}$ & Sau 100 năm \\
\hline Thấp & 4,8 & 13 & 23 & 38 & 56 & 51,2 \\
\hline Trung bình thấp & 8,8 & 26 & 53 & 91 & 144,4 & 135,6 \\
\hline Trung bình cao & 13,2 & 39 & 79 & 137 & 216,6 & 203,6 \\
\hline Cao & 17,1 & 55 & 117 & 212 & 345,0 & 327,9 \\
\hline
\end{tabular}

Tăng cao nhiệt độ. Nhiệt độ trái đất tăng cao, ngoài hiệu ứng làm dâng cao mực nước 
biển toàn cầu do tan băng và giãn nở thể tích khối nước - còn trực tiếp gây ra một số tác động. Vào những năm El-Nino, nhiệt độ tăng cao đột biến, có thể gây chết san hô và ảnh hưởng đến các đối tượng khác. Theo tạp chí : "Sự ấm lên toàn cầu và thế giới thứ 3" (Số 31, tháng 3/1999), do El-Nino nhiệt độ trái đất năm 1998 tăng $0,57^{\circ} \mathrm{C}$ so với giá trị trung bình 30 năm 1961 - 1990 và là cao nhất kế tiếp giữa thế kỷ 19 đến nay.

Tăng cao nhiệt độ theo xu hướng chung ấm lên của trái đất và những thời kỳ nóng vào dịp El-Nino gần đây được nhiều tài liệu khoa học trên thế giới cho thấy là một nguyên nhân gây chết san hô hàng loạt. Vào năm 1998, ở BLV vấn đề san hô chết hàng loạt được thông báo là do sử dụng cyanua $[4,5,6]$. Tuy nhiên, ở đây cũng có thể có sự tham gia của yếu tố nhiệt độ tăng cao của năm 1997 - 1998 theo báo cáo của các trạm quan trắc môi trường ven bờ Việt Nam đã ghi nhận nhiệt độ của nước trung bình tăng cao $1-2^{\circ} \mathrm{C}$ so với những năm không có El-Nino.

Bảng 2 trình bày mối quan hệ giữa 5 yếu tố tác động tự nhiên với các đối tượng tài nguyên và môi trường chịu tác động, trong đó có những yếu tố có thể ghi nhận trực quan, có những yếu tố tiềm ẩn lâu dài.

Bảng 2. Quan hệ giữa các yếu tố tác động tự nhiên và các đối tượng chịu tác động

\begin{tabular}{|c|c|c|c|}
\hline TT & $\begin{array}{l}\text { Tên tác } \\
\text { động }\end{array}$ & Đối tượng bị tác động chủ yếu & Hình thức tác động \\
\hline \multirow[t]{3}{*}{1} & \multirow[t]{3}{*}{$\begin{array}{l}\text { Sóng bão } \\
\text { lớn }\end{array}$} & $\begin{array}{l}\text { Tính ổn định bờ biển và HST bờ } \\
\text { cát }\end{array}$ & Bồi tụ, xói lở bất thường \\
\hline & & Cảnh quan và habitat đảo nổi & Phá hủy trực tiếp \\
\hline & & HST rạn san hô & Phá hủy rạn, bẻ gãy san hô \\
\hline \multirow[t]{2}{*}{2} & \multirow{2}{*}{$\begin{array}{l}\text { Dâng cao } \\
\text { mực nước } \\
\text { biển }\end{array}$} & Ổn định bờ bãi, HST bãi cát biển & Xói lở làm mất bãi cát biển. \\
\hline & & Tài nguyên nước ngầm & Tăng cường nhiễm mặn \\
\hline \multirow[t]{2}{*}{3} & \multirow[t]{2}{*}{ Mưa lớn } & $\begin{array}{l}\text { Bờ đảo (tính ổn định), tài nguyên } \\
\text { đất đảo }\end{array}$ & Xói lở bờ, xói mòn đất \\
\hline & & HST bãi triều rạn đá & Ngọt hóa tức thời \\
\hline \multirow[t]{2}{*}{4} & \multirow{2}{*}{$\begin{array}{l}\text { Tăng cao } \\
\text { nhiệt độ }\end{array}$} & HST rạn san hô & Gây chết san hô \\
\hline & & Tài nguyên đất đảo & Đá ong hóa đất \\
\hline \multirow[t]{2}{*}{5} & \multirow[t]{2}{*}{ Khô hạn } & Tài nguyên nước ngầm & Thiếu nguồn bổ sung nước ngọt \\
\hline & & Tài nguyên đất & Thái hóa đất \\
\hline
\end{tabular}

Trong khuôn khổ bài báo này, xin chỉ nêu ví dụ kết quả đánh giá chi tiết tác động của dâng cao mực biển đối với xói lở bờ biển Bạch Long Vỹ theo công thức Brunn .

Kết quả khảo sát thực địa cho thấy hiện nay bờ đảo xói lở theo mùa tại nơi có bãi cát biển, trên chiều dài $2400 \mathrm{~m}$. Mùa đông, xói lở mạnh trên đoạn bờ Đông Bắc của sườn Tây Bắc đảo; mùa hè xói lở mạnh trên đoạn bờ Đông Nam.Tốc độ xói lở trung bình trong 30 năm qua là $5-7 \mathrm{~cm} /$ năm, tương đối phù hợp với kết quả tính toán trên bảng 3 .

Công thức Bruun (1983), đã được sử dụng để tính toán dự báo tốc độ xói lở bờ cát trong điều kiện dâng cao mực nước biển [14]: $\mathrm{Xh}=\mathrm{la}$

Trong đó: $X$ - Tốc độ lùi của đường bờ (m/năm), 
a - Tốc độ dâng cao mực biển (m/năm),

$\mathrm{h}$ - Độ sâu lớn nhất biến đổi trầm tích gần bờ và xa bờ $(\mathrm{m})$,

1 - Chiều rộng trắc diện bị biến đổi.

Kết quả tính toán (bảng 3) theo số liệu khảo sát [15] cho thấy theo kịch bản 1, tốc độ xói lở bãi trung bình dưới $0,1 \mathrm{~m} / \mathrm{năm}$, ở kịch bản 2 khoảng $0,1-0,5 \mathrm{~m} /$ năm và ở kịch bản 3 là $0,2-0,8 \mathrm{~m} /$ năm. Vào năm 2100 , theo kịch bản 1 , chiều rộng bãi giảm $14-23 \%$, cá biệt $36 \%$. Với kịch bản 2 chiều rộng bãi lớn nhất chỉ còn $18 \mathrm{~m}$ và hầu hết các bãi bị thu hẹp $3 / 4$ chiều rộng, hoặc bị xói lở hoàn toàn.Với kịch bản 3 , bãi hầu như bị xói lở hết vào năm 2100. Bãi biển đảo BLV có chiều ngang hẹp, trung bình 20 - 30m, lớn nhất $50-70 \mathrm{~m}$, chỉ cần tốc độ xói lở không lớn, bãi có thể bị thu hẹp đáng kể hoặc biến mất.

Bảng 3. Dự báo mức độ xói lở bờ đảo Bạch Long Vỹ do dâng cao mực nước biển

\begin{tabular}{|c|c|c|c|c|c|c|c|c|c|}
\hline \multirow{2}{*}{$\begin{array}{l}\text { Mặt } \\
\text { cắt } \\
\text { Bãi }\end{array}$} & \multirow{2}{*}{$\begin{array}{l}\text { Vị trí } \\
\text { bò̀ } \\
\text { đảo }\end{array}$} & \multirow{2}{*}{$\begin{array}{l}\text { Chiều } \\
\text { rộng } \\
\text { bãi (m) }\end{array}$} & \multirow{2}{*}{$\begin{array}{l}\text { Độ cao chân } \\
\text { bãi (m) trên } \\
\text { mực nước } \\
\text { thấp nhất }\end{array}$} & \multicolumn{3}{|c|}{ Tốc độ xói lở (m/năm) } & \multicolumn{3}{|c|}{$\begin{array}{l}\text { Chiều rộng bãi } \\
\text { vào } 2100 \text { (m) }\end{array}$} \\
\hline & & & & KB1 & KB2 & KB3 & KB1 & KB2 & $\begin{array}{c}\mathrm{KB} \\
3\end{array}$ \\
\hline $\mathrm{C} 15$ & $\mathrm{~N}$ & 50 & 1,8 & 0,070 & 0,38 & 0,56 & 43,0 & 12 & 0 \\
\hline$\overline{\mathrm{C} 7}$ & $\mathrm{TN}$ & 12 & 1,3 & 0,023 & 0,12 & 0,19 & 7,7 & 0 & 0 \\
\hline $\mathrm{T} 1$ & $\mathrm{TN}$ & 30 & 2,3 & 0,032 & 0,20 & 0,26 & 26,8 & 10 & 4 \\
\hline $\mathrm{T} 2$ & $\mathrm{TN}$ & 32 & 1,3 & 0,060 & 0,32 & 0,49 & 26,0 & 0 & 0 \\
\hline T3a & $\mathrm{TN}$ & 72 & 2,0 & 0,100 & 0,54 & 0,81 & 62,0 & 18 & 0 \\
\hline $\mathrm{T} 3 \mathrm{~b}$ & TB & 29 & 1,8 & 0,040 & 0,22 & 0,32 & 25,0 & 7 & 0 \\
\hline $\mathrm{C} 20$ & TB & 42 & 1,1 & 0,095 & 0,51 & 0,77 & 32,5 & 0 & 0 \\
\hline
\end{tabular}

Ghi chú: KB1(Kịch bản 1): mục biển dâng cao nhu hiện nay, khoảng 0,25cm/năm. KB2 (Kịch bản 2): mục biển dâng ở mưc trung bình thấp 135,6cm trong 2000 - 2100. KB3 (Kịch bản 3): mục biển dâng ở mức trung bình cao 203,4cm trong 2000 - 2100 (Tài liệu của Cục bảo vệ Môi trường Hoa Kỳ EPA, 1983).

\section{2. Đánh giá mức độ tổn thương}

Khả năng hay mức độ tổn thương chính là mức tổn hại của các đối tượng tài nguyên và môi trường phụ thuộc vào tính nhạy cảm của đối tượng chịu tác động và bản chất, quy mô của các yếu tố, quá trình gây tác động. Căn cứ vào hiện trạng các đối tượng bị tác động và dự báo diễn biến của các yếu tố gây tác động, kết quả đánh giá khả năng tổn thương 13 đối tượng tài nguyên và môi trường do tác động của 5 yếu tố tự nhiên ở khu vực đảo BLV thông qua điểm trọng số được trình bày trên bảng 4 .

Kết quả đánh giá cho thấy tổn thương của nước ngầm gây ra do khô hạn và tổn thương của bờ biển gây ra do sóng bão có trọng số lớn nhất, tối đa 25 điểm. Do dâng cao mực nước biển, bờ biển tổn thương với trọng số 23 điểm do bị xói lở.

Vai trò tác động tổn hại của các yếu tố tự nhiên giảm dần theo thứ tự: 1. Sóng bão lớn; 2Dâng cao mực nước; 3- Mưa lớn; 4- Tăng cao nhiệt độ; 5- Khô hạn.

Tổng hợp lại, mức độ tổn thương của các đối tượng tài nguyên và môi trường do tổ hợp tác động của các yếu tố nguồn giảm dần theo thứ tự: 1- Tính ổn định bờ bãi; 2- Nước ngầm; 3- 
Tài nguyên đất đảo; 4- Hệ sinh thái bờ cát; 5- HST rạn san hô; 6- Cảnh quan, habitat nổi; 7HST bãi triều rạn đá; 8- Nguồn lợi thuỷ sản; 9- Cảnh quan và habitat ngầm; 10- HST đáy mềm; 11- HST đáy cứng; 12- Đa dạng nguồn ven biển; 13- Chất lượng nước ven đảo

Bảng 4. Ma trận đánh giá khả năng tổn thương của các hợp phần tài nguyên và môi trường khu vực đảo BLV do tác động tự

\begin{tabular}{|c|l|c|c|c|c|c|c|}
\hline TT & $\begin{array}{c}\text { Đối tượng } \\
\text { tác động } \\
\text { Đối tượng } \\
\text { tổn thướng }\end{array}$ & $\begin{array}{c}\text { Dâng cao } \\
\text { mực } \\
\text { nước }\end{array}$ & $\begin{array}{c}\text { Tăng cao } \\
\text { nhiệt độ }\end{array}$ & $\begin{array}{c}\text { Mưa } \\
\text { lớn }\end{array}$ & $\begin{array}{c}\text { Sóng } \\
\text { bão } \\
\text { lớn }\end{array}$ & $\begin{array}{c}\text { Khô } \\
\text { hạn }\end{array}$ & Tổng \\
\hline 1 & Cảnh quan và habitat đảo nồi & 6 & 5 & 6 & 12 & 5 & $\mathbf{3 4}$ \\
\hline 2 & Cảnh quan ngầm & 3 & 3 & 3 & 10 & 0 & $\mathbf{1 9}$ \\
\hline 3 & Bờ đảo (tính ồn định) & 23 & 0 & 13 & 25 & 2 & $\mathbf{6 3}$ \\
\hline 4 & Nước ngầm trên đảo & 14 & 8 & 0 & 0 & 25 & $\mathbf{4 7}$ \\
\hline 5 & Chất lượng nước ven đảo & 0 & 1 & 3 & 0 & 0 & $\mathbf{4}$ \\
\hline 6 & Tài nguyên đất trên đảo & 2 & 11 & 13 & 6 & 12 & $\mathbf{4 4}$ \\
\hline 7 & Nguồn lợi thủy sản & 5 & 5 & 5 & 7 & 0 & $\mathbf{2 2}$ \\
\hline 8 & Đa dạng sinh học & 1 & 2 & 1 & 1 & 0 & $\mathbf{5}$ \\
\hline 9 & HST bãi cát & 13 & 2 & 3 & 16 & 3 & $\mathbf{3 7}$ \\
\hline 10 & HST bãi triều rạn đá & 6 & 6 & 8 & 11 & 0 & $\mathbf{3 1}$ \\
\hline 11 & HST rạn san hô & 3 & 15 & 6 & 11 & 0 & $\mathbf{3 5}$ \\
\hline 12 & HST đáy cứng & 1 & 1 & 0 & 4 & 0 & $\mathbf{6}$ \\
\hline 13 & HST đáy mềm & 1 & 1 & 0 & 10 & 0 & $\mathbf{1 2}$ \\
\hline Cộng & $\mathbf{7 8}$ & $\mathbf{6 0}$ & $\mathbf{6 1}$ & $\mathbf{1 1 3}$ & $\mathbf{4 7}$ & $\mathbf{3 5 9}$ \\
\hline
\end{tabular}

Ghi chú: Điểm trọng số cho mức tác động Rất lớn: 21 - 25; Lơn: 161 - 20

Trung bình: 11 - 15; Thấp: 6 - 10; Rất thấp hoặc không tác động: 0 - 5

\section{KHẢ NĂNG TỔN THƯƠNG DO CÁC TÁC ĐộNG NHÂN SINH}

\section{1. Áp lực và tác động}

Dân số cố định trên đảo năm 2009 khoảng 1.420 người và nếu tính cả số lượng lớn ngư dân vãng lai từ các tàu neo đậu quanh đảo thì thường xuyên khoảng 3.500 - 4.000 người với mật độ có lúc xấp xỉ 2.000 người $/ \mathrm{km}^{2}$. Khu vực tập trung dân cao nhất là khu âu tầu và lân cận. Ngư trường BLV sẽ thu hút các đội tàu đánh cá của Hải Phòng và các tỉnh ven bờ của vịnh Bắc bộ, các tỉnh ven bờ phía Nam.

Theo quy hoạch tổng thể tầm nhìn đến 2020 thì cơ cấu sử dụng đất trên đảo nghiêng về các hoạt động dịch vụ hậu cần, kỹ thuật cho nghề cá [16]. Diện tích đất cho phát triển nông nghiệp chỉ có 8,7 ha chiếm tỷ lệ $1,51 \%$ quỹ đất. Hiện nay phát triển nông nghiệp trên đảo chủ yếu là chăn nuôi bò, nhưng đã có ảnh hưởng đến vệ sinh môi trường và thảm thực vật tự nhiên trên đảo. Nuôi trồng thủy sản quanh đảo chủ yếu là nuôi bào ngư (nuôi bãi tự nhiên) và nuôi lồng cá mú mới ở mức thử nghiệm. Hoạt động dịch vụ hậu cần nghề cá khá phát triển cùng với các dịch vụ khác như bưu chính - viễn thông, cấp nước ngọt, lương thực thực phẩm, dầu mõ̃, ngư cụ, nước đá muối, thu mua và chế biến thuỷ sản, sửa chữa nhỏ tàu thuyền ... Cơ sở hạ tầng như đường xá, câu lạc bộ, bệnh xá, trường học tiếp tục 
hoàn thiện và phát triển. Theo quy hoạch thì đất phân bổ cho dịch vụ nghề cá là 14,47ha $(2,52 \%)$, khu neo đậu tàu thuyền 49,08ha $(8,54 \%)$. Tương lai sẽ cho mở rộng âu tàu hiện có ở phía Nam đảo và xây dựng mới 1 âu tàu ở phía Tây đảo. Các hoạt động du lịch trên đảo sẽ được đẩy mạnh với những dự án thí điểm do Tổng đội Thanh niên xung phong đang triển khai.

Bảng 5. Quan hệ giữa các yếu tố tác động nhân sinh và các đối tượng chịu tác động

\begin{tabular}{|c|c|c|c|}
\hline TT & $\begin{array}{l}\text { Tên tác } \\
\text { động }\end{array}$ & Đối tượng bị tác động chủ yếu & Hình thức tác động \\
\hline 1 & Đánh bắt & $\begin{array}{l}\text { Nguồn lợi thuỷ sản, đa dạng sinh } \\
\text { học biển, HST san hô, HST đáy } \\
\text { cứng và bãi triều rạn đá }\end{array}$ & $\begin{array}{l}\text { Khai thác quá mức huỷ hoại } \\
\text { habitat và môi sinh, nguồn } \\
\text { sống bằng các phương pháp } \\
\text { huỷ diệt. }\end{array}$ \\
\hline 2 & $\begin{array}{l}\text { Tràn dầu, ô } \\
\text { nhiễm dầu }\end{array}$ & $\begin{array}{l}\text { Chất lượng nước quanh đảo, hệ } \\
\text { sinh thái bờ cát, nguồn lợi thuỷ } \\
\text { sản, đa dạng sinh học và HST rạn } \\
\text { đá }\end{array}$ & $\begin{array}{l}\text { Tràn dầu, ô nhiễm thường } \\
\text { xuyên và tích luỹ gây hại cho } \\
\text { sinh vật, ảnh ưởng tới nước } \\
\text { sinh hoạt và du lịch }\end{array}$ \\
\hline 3 & $\begin{array}{l}\text { Khai thác vật } \\
\text { liệu xây dựng }\end{array}$ & $\begin{array}{l}\text { Tính ổn định bờ bãi, HST bãi cát } \\
\text { biển, cảnh quan nổi, tài nguyên } \\
\text { đất đảo, HST rạn đá. }\end{array}$ & $\begin{array}{l}\text { Ô nhiễm chất thải rắn, làm } \\
\text { mất và huỷ hoại habitat, sói } \\
\text { lở bờ, mất cảnh quan. }\end{array}$ \\
\hline 4 & $\begin{array}{l}\text { Xây dựng } \\
\text { công trình } \\
\text { trên đảo và } \\
\text { ven đảo }\end{array}$ & $\begin{array}{l}\text { Tính ổn định bờ biển, cảnh quan } \\
\text { và habitat, tài nguyên đất đảo }\end{array}$ & $\begin{array}{l}\text { Thay đổi hình dạng và cân } \\
\text { bằng động lực bờ, sử dụng } \\
\text { mất đất, biến dạng cảnh quan }\end{array}$ \\
\hline 5 & $\begin{array}{l}\text { Giao thông } \\
\text { thuỷ }\end{array}$ & $\begin{array}{l}\text { HST san hô, HST đáy cứng, cảnh } \\
\text { quan ngầm, chất lượng nước }\end{array}$ & $\begin{array}{l}\text { Làm huỷ hoại habitat, gây ồn } \\
\text { và ô nhiễm nước }\end{array}$ \\
\hline 6 & Du lịch & HST san hô, cảnh quan & $\begin{array}{l}\text { ảnh ưởng đến sự bền vững hệ } \\
\text { sinh thái, chất thải rắn }\end{array}$ \\
\hline 7 & Sinh hoạt & $\begin{array}{l}\text { Tài nguyên nước ngầm, chất } \\
\text { lượng nước, cảnh quan nổi }\end{array}$ & $\begin{array}{l}\text { Khai thác quá mức nước } \\
\text { ngột, chât thải (rắn, lỏng, hoá } \\
\text { chất) }\end{array}$ \\
\hline 8 & Canh tác & $\begin{array}{l}\text { Tài nguyên đất đảo, cảnh quan, tài } \\
\text { nguyên nước. }\end{array}$ & $\begin{array}{l}\text { Mất đất, mất lớp phủ thực vật } \\
\text { giữ nước. }\end{array}$ \\
\hline 9 & $\begin{array}{l}\text { Nuôi trồng } \\
\text { biển. }\end{array}$ & $\begin{array}{l}\text { HST đáy cứng, đáy mềm, nguồn } \\
\text { lợi đánh bắt, cảnh quan }\end{array}$ & $\begin{array}{l}\text { Chiếm cứ không gian, ô } \\
\text { nhiễm chất hữu cơ và phú } \\
\text { dưỡng. }\end{array}$ \\
\hline 10 & $\begin{array}{l}\text { Công nghiệp, } \\
\text { thủ công } \\
\text { nghiệp. }\end{array}$ & $\begin{array}{l}\text { Nước ven đảo, cảnh quan, Tài } \\
\text { nguyên nước ngầm, đất đảo }\end{array}$ & Ô nhiễm đát thải lổng, rắn. \\
\hline
\end{tabular}


Hoạt động hàng hải trên khu vực biển BLV sẽ tấp nập hơn, vì thế có thể ra đời các hoạt động cứu hộ và dịch vụ phạm vi rộng rộng hơn. Tiềm năng dầu khí vùng biển BLV có triển vọng lớn và hiện thực, đặc biệt với việc phát hiện mỏ dầu khí gần đây tại giếng Yên Tử thuộc lô 106 với trữ lượng ước tính 700 - 800 triệu thùng dầu và 40 tỷ $\mathrm{m}^{3}$ khí. Khả năng dịch vụ dầu khí tại BLV ngày càng trở thành hiện thực. Nguy cơ ô nhiễm dầu ngày càng lớn do các hoạt động khai thác, vận chuyển và dịch vụ dầu khí và nghề cá. Ngoài ra tỷ lệ rò rỉ dầu khai thác là $0,04 \%$, những sự cố tràn dầu có thể xẩy ra. Ngoài ra còn khả năng tràn dầu xuyên biên giới và tràn dầu không rõ nguồn gốc, điển hình nhất là năm 2007. Tai biến va đâm tầu thuyền có thể xảy ra ở ven đảo, nơi có khá nhiều các mỏm đá ngầm, đá gốc hoặc rạn san hô lập lờ mặt nước, nhất là khi có sương mù và giông bão [8].

Bảng 5 trình bày quan hệ tác động của 10 hoạt động nhân tác đối với các đối tượng chịu tác động chủ yếu thông qua các hình thức tác động. Ở đây muốn nhấn mạnh tới hậu quả môi trường của tăng dân số, ngoài sinh hoạt tác động nghiêm trọng tới chữ lượng và chất lượng nước ngầm còn gây nhiều tác động gián tiếp tới hoạt động kinh tế như xây dựng và khai thác vật liệu xây dựng, du lịch, dịch vụ, đánh bắt và nuôi trồng, ... mà sức ép đáng kể nhất là khai thác thuỷ sản vùng triều và vùng ven đảo. Ảnh hưởng của tiểu thủ công nghiệp tới chất lượng nước môi trường nước ven đảo không lớn.

\section{2. Đánh giá mức độ tổn thương}

Căn cứ vào hiện trạng các đối tượng bị tác động và dự báo diễn biến của các yếu tố gây tác động, kết quả đánh giá khả năng tổn thương 13 đối tượng tài nguyên và môi trường do tác động của 10 yếu tố hoạt động nhân sinh trên nền hiện trạng và quy hoạch phát triển kinh tế - xã hội huyện đảo đến 2020 ở khu vực đảo BLV thông qua điểm trọng số được trình bày trên ma trận bảng 6 .

Điểm trọng số tổn thương cao nhất do tác động của sinh hoạt gây ra đối với nước ngầm; do đánh bắt thiếu quản lý (quá mức, huỷ diệt môi sinh, huỷ hoại habitat) và ô nhiễm dầu gây ra đối với nguồn lợi thuỷ sản, đa dạng loài và HST rạn san hô; do tràn dầu và ô nhiễm dầu gây ra đối với chất lượng nước và các bãi cát ven đảo. Những tổn thương đáng chú ý khác do xây dựng công trình ven đảo và khai thác vật liệu xây dựng đối với sự ổn định bờ đảo; tổn thương do đánh bắt thuỷ sản gây ra với các HST ven đảo ...

Mức độ gây tác động gây tổn hại của các nhân tố áp lực nguồn giảm dần theo thứ tự: 1- Đánh bắt quá mức và huỷ hoại; 2 - Tràn dầu và ô nhiê̂m dầu; 3- Khai thác vật liệu xây dựng; 4- Xây dựng công trình trên và ven đảo; 5- Du lịch; 6- Sinh hoạt; 7Giao thông thuỷ; 8- Canh tác trên đảo; 9- Nuôi trồng biển; 10- Công nghiệp và tiểu thủ công nghiệp.

Mức độ tổn thương của 13 đối tượng tài nguyên và môi trường giảm dần theo thứ tự như sau: 1- Chất lượng nước ven đảo; 2- Hệ sinh thái rạn san hô; 3- Nguồn lợi thuỷ sản; 4- Đa dạng sinh học; 5- Hệ sinh thái bãi cát biển; 6- Hệ sinh thái bãi triều rạn đá; 7- Hệ sinh thái đáy cứng; 8- Nước ngầm; 9- Cảnh quan và habitat nổi; 10- Cảnh quan ngầm; 11- Tính ổn định (bồi, xói) bờ bãi; 12- Tài nguyên đất trên đảo; 13- Hệ sinh thái đáy mềm. 
Bảng 6. Ma trận đánh giá khả năng tổn thương của các hợp phần tài nguyên và môi trường khu vực đảo Bạch Long Vỹ do tác động nhân sinh gây ra

\begin{tabular}{|c|c|c|c|c|c|c|c|c|c|c|c|c|}
\hline TT & Đối tượng & $\begin{array}{l}\text { Xây } \\
\text { dựng } \\
\text { công } \\
\text { trình }\end{array}$ & $\begin{array}{l}\text { Canh } \\
\text { tác }\end{array}$ & $\begin{array}{l}\text { Sinh } \\
\text { hoạt }\end{array}$ & $\begin{array}{l}\mathrm{Du} \\
\text { lịch }\end{array}$ & $\begin{array}{l}\text { Giao } \\
\text { thông } \\
\text { thuỷ }\end{array}$ & $\begin{array}{l}\text { Đánh } \\
\text { bắt }\end{array}$ & $\begin{array}{l}\text { Nuôi } \\
\text { trồng } \\
\text { biển }\end{array}$ & $\begin{array}{l}\text { Tràn, } \\
\text { ồ } \\
\text { nhiê̂m } \\
\text { dầu }\end{array}$ & $\begin{array}{l}\text { Vật } \\
\text { liệu } \\
\text { xây } \\
\text { dựng }\end{array}$ & $\begin{array}{l}\text { CN và } \\
\text { tiểu } \\
\text { thủ } \\
\text { CN }\end{array}$ & Tổng \\
\hline 1 & $\begin{array}{l}\text { Cảnh quan và habitat } \\
\text { đảo nổi }\end{array}$ & 11 & 11 & 5 & 5 & 0 & 0 & 0 & 0 & 12 & 3 & 47 \\
\hline 2 & Cảnh quan ngầm & 3 & 3 & 1 & 8 & 8 & 6 & 5 & 3 & 1 & 0 & 38 \\
\hline 3 & Bờ đảo (tính ổn định) & 20 & 0 & 0 & 0 & 0 & 0 & 0 & 0 & 18 & 0 & 38 \\
\hline 4 & Nước ngầm trên đảo & 3 & 10 & 25 & 0 & 0 & 0 & 0 & 0 & 10 & 3 & 51 \\
\hline 5 & Chất lượng nước ven đảo & 3 & 6 & 6 & 6 & 7 & 10 & 6 & 25 & 6 & 7 & 82 \\
\hline 6 & Tài nguyên đất trên đảo & 8 & 15 & 0 & 0 & 0 & 0 & 0 & 0 & 11 & 3 & 37 \\
\hline 7 & Nguồn lợi thuỷ sản & 3 & 1 & 3 & 6 & 6 & 25 & 6 & 21 & 3 & 1 & 75 \\
\hline 8 & Đa dạng sinh học & 3 & 0 & 2 & 7 & 6 & 25 & 0 & 21 & 2 & 1 & 67 \\
\hline 9 & HST bãi cát biển & 10 & 0 & 3 & 5 & 1 & 5 & 0 & 23 & 16 & 1 & 64 \\
\hline 10 & HSTbãi triều rạn đá & 3 & 1 & 1 & 3 & 1 & 21 & 3 & 18 & 11 & 1 & 63 \\
\hline 11 & HST rạn san hô & 3 & 2 & 1 & 11 & 10 & 25 & 3 & 15 & 3 & 1 & 75 \\
\hline 12 & HST đáy cứng & 1 & 1 & 2 & 1 & 12 & 21 & 8 & 8 & 1 & 1 & 56 \\
\hline 13 & HST đáy mềm & 1 & 1 & 2 & 1 & 1 & 11 & 8 & 8 & 1 & 1 & 35 \\
\hline \multicolumn{2}{|c|}{ Tổng } & 72 & 51 & 52 & 53 & 52 & 149 & 31 & 142 & 95 & 23 & 728 \\
\hline
\end{tabular}

Ghi chú: Điểm trọng số cho mức tác động

$$
\begin{array}{ll}
\text { Rát lơn: 21-25. } & \text { Thấp: 6-10. } \\
\text { Lớn: 16-20. } & \text { Rất thấp: 0-5. }
\end{array}
$$

Trung bình: 11-15. 


\section{V. ĐÁNH GIÁ PHÂN CẤP KHẢ NĂNG TỔN THƯƠNG TÀI NGUYỄN VÀ MÔI TRƯờnG KHU VỰC ĐẢO BẠCH LONG VỸ}

Bảng 7. Tổng hợp mức tác động tiềm năng đối với môi trường và tài nguyên Bạch Long Vỹ

\begin{tabular}{|l|l|c|c|c|}
\hline TT & Đối tượng bị tác động & $\begin{array}{c}\text { Điểm trọng số } \\
\text { tác động tự } \\
\text { nhiên }\end{array}$ & $\begin{array}{c}\text { Điểm trọng số } \\
\text { tác động nhân } \\
\text { sinh }\end{array}$ & $\begin{array}{c}\text { Tổng } \\
\text { họ̣p }\end{array}$ \\
\hline 1 & Cảnh quan và habitat đảo nổi & 34 & 47 & 81 \\
\hline 2 & Cảnh quan ngầm & 19 & 38 & 57 \\
\hline 3 & Bờ đảo (tính ồn định) & 63 & 38 & 101 \\
\hline 4 & Nước ngầm trên đảo & 47 & 51 & 98 \\
\hline 5 & Chất lượng nước ven đảo & 4 & 82 & 86 \\
\hline 6 & Tài nguyên đất trên đảo & 44 & 37 & 81 \\
\hline 7 & Nguồn lợi thuỷ sản & 22 & 75 & 97 \\
\hline 8 & Đa dạng nguồn gen biển & 5 & 67 & 72 \\
\hline 9 & HST bãi cát biển & 37 & 64 & 101 \\
\hline 10 & HST bãi triều rạn đá & 31 & 63 & 94 \\
\hline 11 & HST rạn san hô & 35 & 75 & 110 \\
\hline 12 & HST đáy cứng & 6 & 56 & 62 \\
\hline 13 & HST đáy mềm & 12 & 35 & 47 \\
\hline \multicolumn{2}{|l|}{ Tổng } & $\mathbf{3 5 9}$ & $\mathbf{7 2 8}$ & $\mathbf{1 0 8 7}$ \\
\hline
\end{tabular}

Bảng 8. Phân cấp khả năng tổn thương của các đối tượng tài nguyên và môi trường khu vực đảo Bạch Long Vỹ

\begin{tabular}{|l|r|r|r|l|}
\hline Đối tượng & Rhả năng tổn thương & Cao & $\begin{array}{c}\text { Trung } \\
\text { bình }\end{array}$ & Thấp \\
\hline 1. HST rạn san hô & $\mathrm{X}$ & & & \\
\hline 2. HST bãi cát biển & $\mathrm{X}$ & & & \\
\hline 3. Bờ đảo (tính ồn định). & $\mathrm{X}$ & & & \\
\hline 4. Nước ngầm & & $\mathrm{X}$ & & \\
\hline 5. Nguồn lợi thủy sản & & $\mathrm{X}$ & & \\
\hline 6. HST bãi triều rạn đá & & $\mathrm{X}$ & & \\
\hline 7. Chất lượng nước ven đảo & & $\mathrm{X}$ & & \\
\hline 8. Cảnh quan và habitat nổi & & $\mathrm{X}$ & & \\
\hline 9. Tài nguyên đất đảo & & & $\mathrm{X}$ & \\
\hline 10. Đa dạng sinh học & & & & $\mathrm{X}$ \\
\hline 11. HST đáy cứng & & & & $\mathrm{X}$ \\
\hline 12. Cảnh quan ngầm & & & \\
\hline 13. HST đáy mềm & & & \\
\hline
\end{tabular}

Khả năng tổn thương của các yếu tố, hợp phần tài nguyên và môi trường khu vực đảo BLV được đánh giá kết hợp giữa mức độ thương của chúng dưới tác động gây tổn hại từ nguồn tự nhiên và nguồn nhân thông qua điểm số đánh giá được trình bày trên bảng 7 . 
Khả năng tổn thương của các đối tượng môi trường, sinh thái và tài nguyên phụ thuộc vào quy mô và tính chất của đối tượng gây tác động, mức độ tổn thương và khả năng phục hồi của đối tượng bị tác động. Từ kết quả trình bày ở bảng 7 , có thể xác định các mức tổn thương như sau: Thấp: điểm trọng số dưới 61; Trung bình: 61 - 80; Cao: 81 - 100; Rất cao: trên 100 . Từ đó có thể phân loại mức nhạy cảm cho các đối tượng tài nguyên môi trường và sinh thái khu vực BLV theo thứ tự thấp dần trên bảng 8 .

\section{KẾT LUẬN}

Dự báo trong tương lai, 5 yếu tố dâng cao mực nước, tăng cao nhiệt độ, mưa lớn, sóng bão lớn và khô hạn là những yếu tố tự nhiên biến động bất thường gây tác động tổn hại đến tài nguyên và môi trường khu vực đảo BLV. Trong đó, sóng bão lớn và khô hạn là hai yếu tố có tác động lớn nhất. Dự báo đến năm 2020, có 10 yếu tố hoạt động nhân sinh cơ bản: xây dựng công trình, canh tác; sinh hoạt, du lịch, giao thông thuỷ, đánh bắt thuỷ sản, nuôi trồng biển, tràn dầu và ô nhiễm dầu, vật liệu xây dựng, công nghiệp và tiểu thủ công nghiệp gây tác động tổn hại cơ bản đến tài nguyên và môi trường BLV. Trong đó, đánh bắt quá mức - đánh bắt huỷ hoại và tràn dầu - ô nhiễm dầu là hai yếu tố gây tác động lớn nhất.

Đánh giá tổng hợp tổn hại từ tác động của các yếu tố tự nhiên và nhân tác, khả năng tổn thương của của các đối tượng tài nguyên và môi trường $B L V$ được xác định như sau: Khả năng tổn thương mức rất cao: 1- HST rạn san hô, 2- HST bãi cát biển, 3- Bờ đảo (tính ổn định); Khả năng tổn thương mức cao: 4- Nước ngầm, 5- Nguồn lợi thuỷ sản, 6- HST bãi triều rạn đá, 7- Chất lượng nước biển ven đảo, 8- Cảnh quan và habitat nổi và 9- Tài nguyên đất đảo; Khả năng tổn thương mức trung bình: 10- Đa dạng sinh học và 11- HST đáy cứng; Khả năng tổn thương mức thấp: 12- Cảnh quan ngầm và 13- HST đáy mềm.

\section{TÀI LIỆU THAM KHẢO}

1. Anne de la Vega - Leinert and Robert Nicholls, 2000. Synthesis and upscaling of sea - level rise vulnarability assessment studies. Tiempo 36/37, Sept. 2000, p. 10-14.

2. Nguyễn Hữu Cử, 2006. Nghiên cứu xây dựng giải pháp bảo vệ môi trường phục vụ phát triển bền vững huyện đảo Bạch Long Vỹ. Đề tài cấp Thành phố Hải Phòng. Mã số: ĐT.MT.2005.411. Lưu trữ tại Viện TN\&MT Biển.

3. Nguyễn Đức Cự và Nguyễn Hữu Cử, 1996. Vỏ phong hoá trên đảo Bạch Long Vỹ. Tài nguyên và Môi trường biển. Tập III. Nxb. KH\&KT. Hà Nội. Tr. 80-88.

4. Nguyễn Đức Cự và nnk, 1999. Hậu quả môi trường do đánh bắt cá bằng hoá chất độc xyanua đến hệ sinh thái san hô và nguồn lợi bào ngư vùng biển Bạch Long $\mathrm{V} y$. Tài nguyên và Môi trường biển. Tập VI. Nxb. KH\&KT. Hà Nội. Tr. 39-53.

5. Nguyễn Đức Cự và nnk,1999. Điều tra nghiên cứu nguyên nhân suy thoái môi trường sống của bào ngư, đề xuất các giải pháp phục hồi ở vùng biển quanh đảo Bạch Long Vỹ. Báo cáo đề tài. Lưu trữ tại Viện TN\&MT Biển.

6. Nguyễn Đức Cự, Nguyễn Huy Yết, Nguyễn Chu Hồi, 1999. Hậu quả môi trường do việc đánh bắt cá bằng chất độc xyanua đến hệ sinh thái san hô và nguồn lợi bào ngư vùng biển Bạch Long Vỹ. Tài nguyên và Môi trường biển. Tập IV. Nxb.KH\&KT. Hà Nội. Tr. 39-51. 
7. Trần Văn Điện và nnk, 1997. Tiềm năng vật liệu xây dựng trên đảo Bạch Long Vỹ và vấn đề khai thác sử dụng hợp lý. Tài nguyên và Môi trường biển. Tập IV. Nxb. KH\&KT. Hà Nội. Tr. 106-112.

8. Nguyễn Thị Phương Hoa và Trần Đình Lân, 1998. Tai biến môi trường vùng đảo Bạch Long Vỹ. Tài nguyên và Môi trường biển. Tập V. Nxb. KH\&KT. Hà Nội. Tr. $121-129$.

9. Nguyễn Chu Hồi, Trần Đức Thạnh và nnk, 1993. Điều kiện tự nhiên, tài nguyên thiên nhiên và kinh tế xã hội đảo Bạch Long Vỹ. Báo cáo nhánh đề tài KT - 03 - 19. Lưu trữ tại Viện TN\&MT Biển.

10. Nguyễn Chu Hồi, Trần Đức Thạnh, Đỗ Công Thung và nnk, 1997. Điều tra đánh giá điều kiện tự nhiên và tài nguyên vùng biển quanh đảo Bạch Long Vỹ phục vụ một số nhiệm vụ kinh tế - xã hội cấp bách và phát triển bền vững. Lưu tại Viện TN\&MT Biển.

11. Lăng Văn Kẻn và Nguyễn Văn Tiến, 1999. Báo cáo chuyên đề "Khu bảo tồn biển Bạch Long Vỹ" thuộc Dự án "Quy hoạch hệ thống các khu bảo tồn biển Việt Nam". Lưu tại Viện TN\&MT Biển.

12. Trần Đình Lân, Nguyễn Hữu Cử, Trần Đức Thạnh và nnk, 1996. Đánh giá tiềm năng vật liệu xây dựng vùng đảo Bạch Long Vỹ. Báo cáo chuyên đề: " Điều tra đánh giá điều kiện tự nhiên và tài nguyên thiên nhiên vùng biển quanh đảo Bạch Long Vỹ phục vụ một số nhiệm vụ kinh tế xã hội cấp bách và phát triển lâu bền". Lưu tại Viện TN\&MT Biển.

13. Trần Đình Lân và nnk. 1996. Hình thái địa hình và trầm tích hiện đại vùng biển ven đảo Bạch Long Vỹ. Tài nguyên và Môi trường biển T.II. Nxb. KH \& KT. Hà Nội. Tr. 27 - 35.

14. Trần Đức Thạnh và nnk, 1994. Áp dụng qui tắc Bruun để tính toán dự báo xói lở các bãi biển ven bờ Hải Phòng khi có sự dâng cao của mực nước biển. Tài nguyên và Môi trường biển. T. II. Nxb. KH \& KT. Hà Nội. Tr. 48 - 53.

15. Trần Đức Thạnh (chủ biên), 1998. Điều tra cơ bản môi trường biển Bạch Long Vỹ. Đề tài cấp thành phố Hải Phòng. Lưu trữ tại Viện TN\&MT Biển.

16. Trần Đức Thạnh (chủ biên), 2005. Quy hoạch tổng thể phát triển kinh tế xã hội huyện đảo Bạch Long Vỹ đến năm 2010 và 2020. Lưu trữ tại Viện TN\&MT Biển.

17. Trần Đức Thạnh, Nguyễn Văn Quân và nnk, 2010. Quy hoạch chi tiết khu bảo tồn biển Bạch Long Vỹ - Hải Phòng. Lưu trữ tại Viện TN\&MT Biển.

18. Phạm Thược, 2003. Sử dụng hợp lý và quản lý đa dạng sinh học ở vịnh Bắc bộ. Tuyển tập Tài nguyên và Môi trường Biển, T. IX. Nxb. KH\&KT. Hà Nội. Tr. 205-228.

19. Trần Văn Trị và nnk, 1977. Địa chất đảo Bạch Long Vỹ. Địa chất. Số 132. Hà Nội.

20. Phạm Quang Trung và nnk, 1999. Bàn về địa tầng đảo Bạch Long Vỹ. Tạp chí Dầu khí. Số 6. Tr. 4-17.

21. Nguyễn Hưu Tứ, 1994. Thảm thực vật đảo Bạch Long Vỹ. Tuyển tập các công trình nghiên cứu địa lý. Nxb. KH\&KT. Hà Nội. 


\title{
ESSESSMENT OF AVAILABLE VULNERABILITY FOR THE RESOURCES AND ENVIRONMENT IN BACH LONG VY AREA
}

\section{TRAN DUC THANH, NGUYEN VAN QUAN}

\begin{abstract}
Summary: Locating in the middle of the Gulf of Tonkin, Bach Long Vy island possesses a great potential for economic - social development and natural conservation. However, its resources and environment are strongly impacted by adverse natural factors included climate change, and human activities. Using the matrix analysis, the available vulnerability for 13 objects of resources and environment in Bach Long Vy island area was estimated generally by the impacts from 5 adverse natural factors and 10 human factors. The objects of resources and environment were classified into 4 groups distinguished by vulnerable levels. The group of very high vulnerability consists of: 1-coral reef ecosystem, 2- beach ecosystem and 3- eroded coast; The group of high vulnerability: 1- underground water, 2- fishery stocks, 3- ecosystem of tidal rocky flats, 4- water quality around the island, 5- island landscape and habitat, 6- land resources on the island; The group of medium vulnerability: 1- biodiversity and hard bottom ecosystem; The group of low vulnerability: 1- underwater topography and soft bottom ecosystem.
\end{abstract}

Ngày nhận bài: 22 - 12 - 2011

Ngườ nhận xét: PGS. TS. Đỗ Công Thung 